\title{
Total Quality Management Development and Sharia Governance Efforts in Sharia Micro Financial Institutions to Improve Market Share
}

\author{
Ervicaninda Herry ${ }^{1}$, Pramudia Yuli Eka Permana ${ }^{1}$, Wisnu Bayu Aji ${ }^{1}$, Ridan Muhtadi ${ }^{2}$ \\ Faculty of Economics and Business, Universitas Airlangga, Surabaya, Indonesia ${ }^{1}$, \\ STAI Miftahul Ulum, Pamekasan, Indonesia² \\ ervicaninda@gmail.com
}

\begin{abstract}
An important pillar in the development of Islamic microfinance institutions is Total Quality Management and Sharia Governance. This pillar is the main differentiator between conventional Islamic finance institutions. Institutional efforts to provide satisfaction to customers. The concept of quality (quality) for service and non-service basically includes various things that are focused on the customer. Shari'ah supervision is needed to ensure the implementation of Shari'ah principles in the financial institution, which is played by the Shari'ah Supervisory Board. Implicitly this shows that the practice of shari'ah microfinance institutions has not been concerned with shari'ah principles and the quality of good governance, one of the causes of reputation and public trust in Islamic microfinance institutions will also have an impact on community loyalty use the services of a Shari'ah microfinance institution. Improved reputation and customer trust can be used as an indicator of the success of the development of Islamic microfinance institutions and at the same time predicting their future success in order to increase market share.
\end{abstract}

Keywords: Microfinance Institutions, Total Quality Management, Sharia Governance, Market Share

\section{INTRODUCTION}

The condition of MSMEs in Indonesia is supported by the background of MSME actors. Actors of MSMEs have business reasons because of the existence of safe and large business opportunities and market share, a small proportion due to heredity and no opportunity in other fields. [1] MSMEs in Indonesia have the role of creating jobs and producing added value. [2] However, MSMEs also face various problems in running a business. According to Aslichan et al. (2009) the development of MSMEs faces a fundamental problem which broadly covers: (1) the difficulty of access to MSMEs to the market for the products they produce, (2) the weak development and strengthening of businesses and (3) limited access to financing from formal financial institutions, especially banking. [3]

Under these conditions, microfinance institutions have a strategic function as alternative financial institutions for MSMEs in obtaining funding in addition to funding from banks. One of the Islamic microfinance institutions that provides funding for MSMEs is the Baitul Mal wa Tamwil (BMT). BMT is a sharia microfinance institution (LKMS) that grows from the community and develops very rapidly. BMT has a very strategic role in promoting society, especially the lower classes and its role in alienating the community from religious practices.

Sharia Financial Institutions must adhere to sharia principles and make a change impact on the welfare of society supported by high trust from the community. With that trust, how does LKS provide the best service so that it gives satisfaction to its customers. The problems discussed in this study are concerning the actors of Islamic financial institutions, especially in the Baitul Maal wa Tamwil (BMT) 
towards the implementation of sharia management. This problem is interesting as the development of Islamic financial institutions grows rapidly.

Based on sharia banking statistics, the number of Islamic Banks as of June 2018 has reached 34 units consisting of 13 Sharia Commercial Banks (BUS) and 21 Sharia Business Units (UUS). In addition, the number of Islamic People's Financing Banks (BPRS) has reached 168 units in the same period. In June 2018 there were 693 Operational Headquarters / Branch Offices (138 BUS Branch Offices and 103 UUS Branch Offices), 1,449 Sharia Branch Offices / Service Units and 427 Cash Offices. [4]

The Islamic finance industry is increasingly facing many challenges due to the joining of a number of institutions, inter-organizational collaboration, the development of various products and services, and quality improvement. To respond effectively to these challenges, the creation of systems that meet the level of "quality" that is in accordance with the concept of sharia is a real vital issue that is challenging.

Optimizing its functions and roles, managerial revitalization of Islamic Microfinance Institutions (LKMS) in a better direction is needed. Sharia Financial Institutions must meet quality management standards in order to gain great trust from the public. Moreover, the quality performance of Islamic Financial Institutions needs attention so that the objectives of the institution's existence can be achieved. Quality standards are something that is important for an organization including Islamic Financial Institutions although the term quality is initially used by companies as an effort to improve product quality to provide satisfaction to consumers.

\subsection{Location And Time Of Research}

\section{RESEARCH METHOD}

The location of the study was conducted at the Syariah Nuri Cooperative BMT located in East Java. The time needed for this study is 1 month in January 2019. Two types of data used in this study are primary data and secondary data. Primary data is obtained through in-depth interviews with selected internal respondents, namely administrators and managers. While secondary data is obtained through literature studies and access to data and reports.

\subsection{Types and Data Sources}

The types and sources of data used are primary data and secondary data. Primary data obtained by direct interviews with respondents. Respondents selected in this study used a purposive sampling method. Determination of respondents has competence in the field to be studied and has experience in BMT organizations. Respondents were administrators and management of Nuri Syariah Cooperative BMT. Furthermore, secondary data is obtained to supplement primary data through literature studies and access to data and reports.

\subsection{Data Methods and Analysis}

Quantitative and qualitative data are analyzed descriptively which are presented in the form of tables, images and matrices. The stages in data analysis include identifying internal and external strategic factors of the organization that affect the organization based on health performance analysis, direct observation, and interviews, evaluating the internal environment of the organization with the IFE matrix and external environment using EFE matrix. The assessment includes weighting and ranking of each strategic factor obtained. From the results of each research, interpretations were then made, analyzing using the IE matrix to find out the position of the organization based on the IFE and EFE matrices that had been obtained, conducting a SWOT analysis to obtain alternative strategies based on adjusting internal and external strategic factors of the organization, developing alternative strategies generated from the IE and SWOT matrices, and analyzes priority strategies recommended to the organization. 


\section{DISCUSSION}

Before discussing about Sharia Microfinance Institutions (LKMS), the definition of Microfinance Institutions in general will be explained first. According to Law No. 1 of 2013 Chapter I Article 1 About Microfinance Institutions, MFIs are specialized financial institutions established to provide business development and community empowerment services, either through loans or financing in micro-scale businesses to members and the community, deposit management, and the provision of development consulting services businesses that are not solely seeking profits. Whereas what is meant by Islamic Microfinance Institutions (LKMS) according to Law No. 1 of 2013 Chapter IV Article 12 is a microfinance institution that uses sharia principles with the Sharia Supervisory Board (DPS) to oversee operations in accordance with the fatwa of the National Sharia Council (DSN). In operational terms, Sharia Financial Institutions are within the corridors of the principle that includes:1)Justice, which is sharing profits on the basis of real sales according to the contributions and risks of each party. 2)Synergize for profit. 3)Transparency, Islamic financial institutions will provide financial reports openly and continuously so that investor customers can find out the condition of their funds; and4)Universal, which means not distinguishing ethnicity, religion, race, and class in society in accordance with Islamic principles as rahmatan lilalamin.

Based on a study from the Sharia Economic Outlook 2018 Microfinance Institutions in Indonesia, it is generally divided into two major parts, namely MFIs in the form of non-Bank Banks and MFIs. For MFIs in the form of banks, there are three categories, namely: BPR / BPRS, micro units from Commercial Banks, and Village Credit Bodies (BKD). While non-bank MFIs are divided into formal and non-formal institutions. Formal non-bank MFIs are Cooperatives, Islamic Financial Services Cooperatives, Pawn Institutions, Sharia Pawn Institutions, Rural Credit Fund Institutions and government-owned Zakat Institutions. Whereas non-formal ones are zakat institutions that form NGOs, Baitulmal WaTamwil (BMT), and social gathering programs.

Sharia Microfinance Institutions are operated with the principle of profit sharing, developing micro business in order to raise the degree and dignity and defend the interests of the poor, grown on initiatives and initial capital from local community leaders based on the economic system Salaam: safety, peace and well-being. So it is necessary to improve the quality of the institution.

\section{Total Quality Management}

Total quality management, Tenner De Toro [5] presents three main principles in TQM. These three things are: (a) Focus on customers (focus on customers). The point is the attention of an organization or institution to its customers both internally and externally. Quality is based on the concept that everyone has customers. Customer desires and expectations must be fulfilled at all times by an organization. Therefore, to determine customer desires, a number of analyzes must be carried out so as not to misstep; (b) Continuous process improvement. The concept of continuous quality improvement starts from the assumption that a work result is an accumulation of a series of interrelated work steps until output appears. Continuous attention to each step in the work process is one thing that must be done in order to reduce the different outputs and improve the process of trustworthiness. The first goal of continuous improvement is a trusted process in the sense that the output produced at any time will be the same and in accordance with the specified standards. If the variation in output has been minimized but the results have not yet been accepted, the second goal of process improvement is to redesign the production process so as to obtain better results and in accordance with customer expectations; (c) Total involvement. This approach begins with the existence of active leaders from senior management and includes efforts to use the expertise of the employees of the organization to gain competitive advantage in the market. Employees at every level are equipped to improve work outcomes by working together in a working structure that is flexible in solving problems, improving processes, and giving satisfaction to customers. Likewise, outside work partners must be actively involved by working with educated employees to benefit the organization.

From the description above, the author tends to choose Tenner-DeToro's opinion to be used as an analysis knife to examine the management of BMT. This election is not intended to demean other theories but to facilitate the writer to analyze the collected data. By using these three principles, management analysis is felt to be easier and focused. 
The concept of quality management is also increasingly emphasized in the Islamic International Rating Agency (IIRA) by making aspects of quality management one of the evaluation criteria in Sharia Quality Rating (SQR). The SQR evaluation criteria include the Sharia Committee, Internal Sharia Control, Accounting Standards, Training and Human Resources, Zakat, Social Impact, Modes of Financing, Identity and Corporate Image (Zaidi, 2006). [6]

In Bahrain, the Quality Management System (QMS) model has begun to be widely applied by Islamic banking. The QMS model that is designed and constructed for Islamic banking includes the following elements. [7]

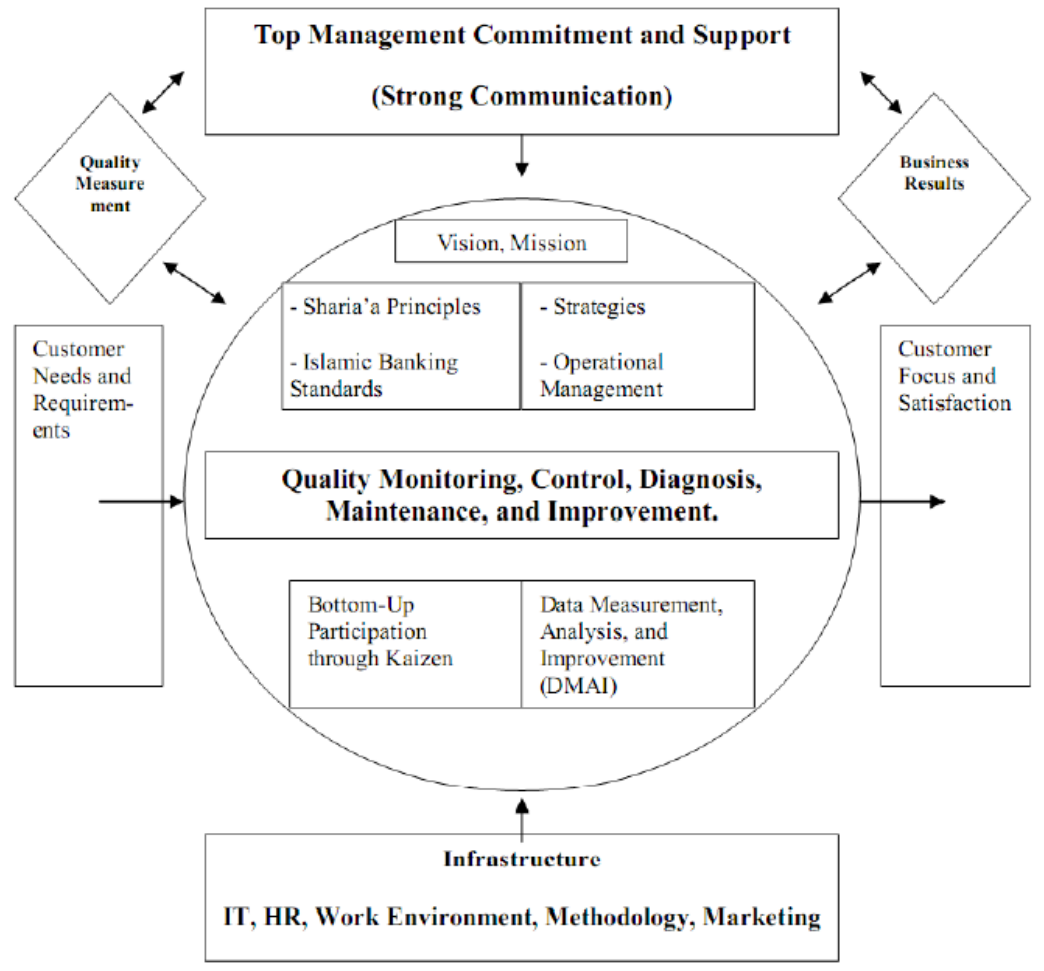

Fig 1. Framework of the Business Model Quality Management System in the Sharia Banking Sector Source: (Saleh, 2005)

The figure above shows the QMS model applied to Islamic banking in Bahrain. The QMS model contains 8 (eight) elements, namely management leadership and commitment, Islamic bank direction and contribution; including vision, mission, strategic direction, market focus, and distinguished tactics, customer focus on one of the driving forces, core business through Sharia principles and its compliance, quality practice tools and methodologies, bottom up contributions (through employees), competitive infrastructure, data measurement, analysis, and improvements.

Strong management leadership is very influential on the company's ability to lead the market. A company leader must know the needs of the people involved in the company and jointly make the needs of the company's stakeholders a common goal of the organization. Managers must understand and analyze the influence of knowing the organization's business objectives with the values believed in working practices together with members of the organization.

Islamic banks should include an Islamic vision in addition to their commercial goals. Building vision, mission, tactics is the initial strategy of planning, but this cannot be realized if it is not supported by people who work in the bank. In this development, the spread of vision, mission and strategy by top management is an important issue.

Banks that operate their operations based on sharia principles must be ensured by the practice as desired by sharia principles. Business organizations usually have quality departments and internal audits to ensure that practices are in accordance with what is desired by organizational policy. This also applies to 
the banking industry which has an internal audit department carrying out the above tasks. On the other hand, Islamic banking in addition to providing internal audit departments, must also carry out the task of checking compliance with business operations against sharia practices and standards.

In the quality management system model above, one that is essential is to involve the lower levels of banking management to participate in developing and improving their practices and circumstances to improve products and services easily. Improving team performance is not a forced activity, but the beliefs and cultural changes that will determine. These changes can be made through commitment from top management to all people in the bank. In addition, the most important thing here is that management makes regulations and regulations for voluntary activities of its employees to be rewarded for helping to implement Islamic banking products and services well.

\section{Sharia Governance}

The term sharia governance in this study was developed from the concept of Good Corporate Governance (GCG) and shariah compliance. The principles of GCG are universal principles, while shariah compliance is the operational principles of Islamic banks. GCG is an arrangement and institutional relationship that directs and controls a company ". [8] Provisions of article 1 point 6 of Bank Indonesia Regulation Number 8/4 / PBI / 2006 concerning Implementation of Good Corporate Governance for Commercial Banks, namely: good corporate governance is a bank governance that applies the principles of transparency, accountability, accountability ( responsibility), independence (independency), and fairness (fairness). In the Indonesian Banking GCG guidelines issued by the National Committee on Corporate Governance (KNKCG), there are 5 principles in implementing good corporate governance, namely: (1) transparency (transparency); (2) accountability; (3) responsibility; (4) independence (independency) and (5) fairness.

In addition, the results of IRTI's research show that the implementation of GCG has not been implemented well in Islamic banking in various countries. GCG implementation is evident in research in several Islamic financial institutions in the Muslim world that can enhance the reputation and trust of the people in Islamic banks. According to Chapra, failure in applying sharia principles will make customers move to other banks by $85 \%$. [9] Therefore, the application of sharia principles (shariah governance) is a necessity for Islamic banking in an effort to improve reputation and trust in Islamic banking, as well as protect the interests of stakeholders in order to portray a healthy and trusted Islamic banking system.

In Islamic teachings, the five basic principles of GCG above are in accordance with Islamic norms and values in the activities and lives of a Muslim. Islam is very intense teaches the application of principles' is (justice), tawazun (balance), mas'uliyah (accountability), morality (moral), siddiq (honesty), trust (fulfillment of trust), fatanah (intelligence), tabligh (transparency, openness ), hurriyyah (independence and freedom that is responsible), ihsan (professional), wasatan (reasonableness), ghirah (Islamic militancy), idarah (management), khilafah (leadership), 'aqeedah (faith), ijabiyah (positive thinking), raqabah (supervision), qira'ah and islah (organizations that continue to learn and always make improvements).

Whereas shariah compliance is the obedience of Islamic banks to sharia principles. Sharia Bank is a financial institution that operates in accordance with Islamic sharia principles, meaning that the bank is operating in compliance with Islamic sharia provisions, especially concerning the procedures for making Islamic prayers. [10] Demands for fulfilling sharia principles (shariah compliance), if referred to the history of the development of Islamic banks, are important because the main reason for the existence of Islamic banking is the emergence of awareness of Muslim communities who want to carry out all their financial activities based on the Qur'an and Sunnah. Therefore, guarantees regarding compliance with sharia (shariah compliance) from all activities of managing customer funds by Islamic banks are very important in the business activities of Islamic banks. The results of Chapra \& Ahmad's research also emphasize this, where a total of 288 customers (62\%) of 463 customers involved in the governance (GCG) survey they conducted (from 14 Islamic banks in Bahrain, Bangladesh and Sudan) answered that they would move their funds to other Islamic banks if it is suspected that "sharia violations" occur in the operations of Islamic banks. [9] Basically sharia compliance can be used in Islamic microfinance institutions. This relates to the pattern of institutional management so that it can be in accordance with Islamic Sharia in every pattern of its activities. Compliance and compliance with sharia principles is often questioned by customers. Implicitly this shows that the practice of Islamic financial institutions has so far been less concerned with sharia 
principles, which is one of the causes of low reputation. Reputation plays an important role in establishing cooperative relationships between institutions and customers. In the long term, reputation has an impact on customer trust in the institution. Improved reputation and trust in sharia financial institutions is one of the performance indicators in increasing market share.

Analysis of the Performance ofBMT the Nuri Syariah Cooperative

The results of the identification of internal and external strategic factors were obtained by 32 factors consisting of 8 factors of strengths, weaknesses, opportunities and threats. The results of the scores of the internal strategic factor values of BMT Koperasi Syariah Nuri amounted to 2.497 which meant having a weak internal position (David 2015) [11] with detailed results in Table 1.

\begin{tabular}{|c|c|c|c|}
\hline Strength & Score & Weakness & Score \\
\hline Process and financing conditions & 0.239 & Problem financing & 0.075 \\
\hline $\begin{array}{l}\text { Implementation and application } \\
\text { of sharia principles }\end{array}$ & 0.219 & Number of marketing staff & 0.093 \\
\hline $\begin{array}{l}\begin{array}{l}\text { Services to members } \\
\text { customers }\end{array}\end{array}$ & 0.219 & $\begin{array}{l}\text { Availability of capital } \\
\text { (liquidity) }\end{array}$ & 0.102 \\
\hline Products offered & 0.190 & Facilities and infrastructure & 0.112 \\
\hline Bookkeeping system & 0.188 & Business location & 0.127 \\
\hline $\begin{array}{l}\text { Management supervision and } \\
\text { sharia principles }\end{array}$ & 0.180 & Promotion carried out & 0.137 \\
\hline Employee turnover rate & 0.172 & HR Competence & 0.138 \\
\hline $\begin{array}{l}\text { Fostering and mentoring } \\
\text { customers' businesses }\end{array}$ & $\mathbf{0 . 1 7 0}$ & $\begin{array}{l}\text { Coaching, HR education } \\
\text { and training }\end{array}$ & 0.139 \\
\hline Total Strengths & 1,576 & $\begin{array}{ll}\begin{array}{l}\text { Total } \\
\text { (Weaknesses) }\end{array} & \text { Weaknesses }\end{array}$ & 0.922 \\
\hline
\end{tabular}




\begin{tabular}{|c|c|c|c|}
\hline Opportunities & Score & Threats & Score \\
\hline $\begin{array}{l}\text { Micro entrepreneurs who are } \\
\text { interested in cooperative } \\
\text { services }\end{array}$ & 0.245 & $\begin{array}{l}\text { Funding costs from } \\
\text { banking institutions }\end{array}$ & 0.261 \\
\hline $\begin{array}{l}\text { The desire of the people to } \\
\text { practice Islamic law }\end{array}$ & 0.212 & $\begin{array}{l}\text { Increase in prices of basic } \\
\text { commodities and basic } \\
\text { electricity tariffs }\end{array}$ & 0.241 \\
\hline $\begin{array}{l}\text { Community understanding of } \\
\text { cooperatives and the } \\
\text { application of sharia }\end{array}$ & 0.183 & $\begin{array}{l}\text { Competition with other } \\
\text { financial institutions }\end{array}$ & $\mathbf{0 . 1 7 7}$ \\
\hline $\begin{array}{l}\text { Outside parties trust as } \\
\text { partners }\end{array}$ & 0.138 & $\begin{array}{l}\text { Development of } \\
\text { microcredit from banks / } \\
\text { financial institutions }\end{array}$ & 0.174 \\
\hline $\begin{array}{l}\text { Government regulation on } \\
\text { KSPPS }\end{array}$ & 0.132 & & \\
\hline $\begin{array}{l}\text { Capital loans from sharia } \\
\text { financial / banking institutions }\end{array}$ & 0.119 & & \\
\hline $\begin{array}{l}\text { Strengthening programs from } \\
\text { the Government }\end{array}$ & 0.118 & & \\
\hline $\begin{array}{l}\text { Easy, inexpensive and fast } \\
\text { financing needs }\end{array}$ & 0.108 & & \\
\hline 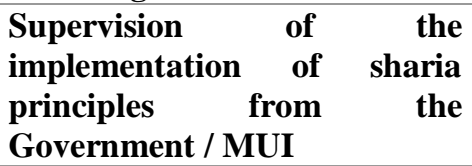 & 0.099 & & \\
\hline $\begin{array}{l}\text { Government attention to the } \\
\text { development of KSPPS }\end{array}$ & 0.069 & & \\
\hline $\begin{array}{l}\text { Information technology-based } \\
\text { banking product services }\end{array}$ & 0.066 & & \\
\hline $\begin{array}{l}\text { Establishment and } \\
\text { development of the KSPPS } \\
\text { network through associations / } \\
\text { associations }\end{array}$ & 0.058 & & \\
\hline $\begin{array}{l}\text { Total Opportunities } \\
\text { (Opportunities) }\end{array}$ & 1,547 & Total Threat (Threats) & 0.853 \\
\hline & \multicolumn{3}{|c|}{ External Factor Evaluation $\quad \mathbf{2 . 0 1 0}$} \\
\hline
\end{tabular}

Table 1. Results of Internal Factor Evaluation Score (IFE)

Whereas the score score of 2.010 internal BMT Koperasi Syariah Nuri strategic factors which means BMT Tawfin utilizes existing opportunities or avoids threats that emerge with an average response (David 2015) [11] with details in Table 2.

Table 2. Results of External Factor Evaluation Score (EFE)

The strategy for developing the Sharia Cooperative BMT has implications for various aspects, namely 1) increasing Total Quality Management in accordance with the mission of the Nuri Syariah Cooperative BMT by improving the DPS management and risk management function, 2) improving the quality of services by increasing competence, skills and knowledge of resources human beings through training and guidance especially in the field of marketing and improvement of information technology that 
can meet the needs of members and customers, 3) increase institutional capacity by establishing mutually beneficial cooperation / partnerships with Islamic microfinance institutions and sharia banking as well as being active in associations to develop BMT in broader scope.

\section{CONCLUSION}

The strategy of developing Sharia MicrofinanceInstitutions to increase market share, it must be considered first two important factors,namely internal factors (as a factor of strengths and weaknesses) and external factors (as a factor of opportunity and threat). It must be based on total quality management and sharia governance.Based on the analysis carried out it can be concluded that the health performance of BMT Syariah Nuri Cooperative obtained an overall score of 51.70 with the criteria in Supervision which included in the unhealthy category. This condition is caused by poor quality asset and liquidity, inefficient operating activities and independence and low growth. The results of the analysis of internal strategic factors and showing the position of the Nuri Syariah Cooperative BMT are in cell V with a strategy of keeping and maintaining (hold and maintain). While the results of the analysis of internal and external strategy factors using the SWOT matrix produce priority strategies in the form of 5 WO (Weakness Opportunities) strategies that produce 5 proposed strategies, namely (1) Developing program linkages with Islamic financial and banking institutions in obtaining low-cost funds (2) Adding one salesperson who has the ability to manage the collection and placement of funds (funding and lending), (3) Enhancing the risk management oversight function in operations through improving Standard Operating Operations and Standard Operating Procedures, establishing a Sharia Supervisory Board (DPS), improving handling problematic financing and re-empowerment of committees established in the organizational structure, (4) improving services to members, customers and society (social) through improving facilities and infrastructures, especially information technology services that can reach and meet the needs of members and re-empower ite-committee formed in the organizational structure, (5) Improving services to members, customers and society (social) through improving facilities and infrastructure, especially information technology services that can reach and meet the needs of members and customers, providing cheap and fast service products but remain in accordance with sharia principles and provide collection and distribution services for zakat, infaq, shodaqah and waqf (ZISWAF), (6) Improve HR competencies through training and coaching and provide performance-based awards to focus on business development in accordance with sharia principles.

\section{REFERENCES}

[1] Tambunan T.T.H. 2009. UMKM di Indonesia. Jakarta (ID): Ghalia Indonesia

[2] Najib M, Kiminami A. 2011. Innovation, cooperation, and business performance some evidence from Indonesian small food processing cluster. Journal of Agribusiness in Developing and Emerging Economies. 1(1):75-96.

[3] Aslichan, Hubeis M, Sailah I. 2009. Kajian Peniliaian Kesehatan Dalam Rangka Mengevaluasi Kinerja Lembaga Keuangan Mikro Syariah Baitul Maal wat Tamwil (Kasus BMT Bina Umat Sejahtera Lasem Rembang), Jurnal Manajemen Pengembangan Industri Kecil Menengah Sekolah Pascasarjana IPB, 4(2), 195-205

[4] Otoritas Jasa Keuangan, June 2018

[5] Tenner, Arthur R., and Irving J. DeToro, Total Quality Management, Three Steps to Continuous Improvement, Massachusetts: Addison-Wesley Publishing Company, Inc, 1992.

[6] Zaidi, J. (2006). Syari'a Quality Rating. AAOIFI Annual Conference Islamic Banking and Finance, 4 12.

[7] Saleh, K. (2005). Quality in Islamic Banking Sectors Model and Framework, Case: Kuwait Finance House-Bahrain. Australian Organisation for Quality.

[8] Mervin K. Lewis dan Latifa M. Algaud, Perbankan Syariah Prinsip Praktek Prospek (Jakarta: PT. Serambi Ilmu Semesta, 2001), 200. 
[9] M. Umer Chapra and Habib Ahmed, "Corporate Governance in Islamic Financial Institutions." Occasional Paper No. 6, (Islamic Research and Training Institute/Islamic Development Bank, Jeddah (2002) 12-13.

[10]Muhammad Syafi'i Antonio, Bank Syariah Bagi Banker Dan Praktisi Keuangan (Jakarta Tazkia Institute, 1999), 12.

[11] David FR. (2015). Strategic Management Concept and Case, Ed ke-15, Essex (UK): Pearson Education Limited. 